Intersections

Canadian Journal of Music

Revue canadienne de musique
Intersections CANADAN TOURAAL OP NUST

\title{
The Tristan Chord Resolved
}

\section{Nathan Martin}

Volume 28, numéro 2, 2008

URI : https://id.erudit.org/iderudit/029953ar

DOI : https://doi.org/10.7202/029953ar

Aller au sommaire du numéro

Éditeur(s)

Canadian University Music Society / Société de musique des universités canadiennes

ISSN

1911-0146 (imprimé)

1918-512X (numérique)

Découvrir la revue

Citer cet article

Martin, N. (2008). The Tristan Chord Resolved. Intersections, 28(2), 6-30.

https://doi.org/10.7202/029953ar
Résumé de l'article

Un passage peu remarqué du traité de Moritz Hauptmann, Die Natur der Harmonik und der Metrik, offre une description qui pourrait presque décrire la progression initiale de Tristan de Wagner. Cet article survole différentes analyses de l'accord de Tristan publiées dans la littérature spécialisée, et défend les mérites d’une nouvelle interprétation dérivée de celle d'Hauptmann.
Tous droits réservés (C Canadian University Music Society / Société de musique des universités canadiennes, 2009
Ce document est protégé par la loi sur le droit d'auteur. L'utilisation des services d'Érudit (y compris la reproduction) est assujettie à sa politique d'utilisation que vous pouvez consulter en ligne.

https://apropos.erudit.org/fr/usagers/politique-dutilisation/ 


\title{
THE TRISTAN CHORD RESOLVED
}

\author{
Nathan Martin
}

I begin with the obvious: the first chord of Wagner's Tristan Prelude-F-B$D \#-G \sharp-i s$ notoriously resistant to analysis, or at least seemingly impervious to any consensus amongst analysts (ex. 1). This very resistance has naturally encouraged a proliferation of attempts. By the early 1920s, Alfred Lorenz (1924) could write of "that Sphinx-chord, which has already occupied so many minds" [jener Akkordsphynx, die schon so viele Geister beschäftigt hat] and expect the reference to be understood immediately. Some thirty-eight years later, Martin Vogel (1962) devoted a book-length study to the secondary literature on the chord. And Vogel's catalogue could be augmented considerably today. Indeed, as Robert Wason (1982) notes, the Tristan chord has almost seemed to serve as a touchstone against which any theory of harmony must prove itself. The chord's numerous cameos in the recent literature, moreover, suggest that more than a hundred years of debate have done little to diminish its capacity to fascinate-and to vex-music theorists. ${ }^{1}$

In light of the sheer volume of commentary that the Tristan chord has occasioned, my title is no doubt presumptuous. I take some solace, though, in the fact that I do not make the claim on my own behalf, for, curiously enough, and despite all the critical attention the Tristan chord has received, one intriguing piece of evidence has been overlooked almost entirely. In a little-noticed passage from Die Natur der Harmonik und der Metrik, a text that appeared four years before Wagner began composing Tristan, Moritz Hauptmann described precisely the harmonic progression that opens Wagner's Prelude. ${ }^{2}$ My purpose in writing is both to draw attention to Hauptmann's discussion and to defend the analysis of the Tristan chord that it suggests as essentially sound.

Before turning to the details of Hauptmann's text, it is appropriate to review a number of standard explanations of the chord. My survey will be representative rather than exhaustive and systematic rather than historical. It will also be artificially limited: I propose to consider only those analyses that enjoy wide currency in North America or have prominent adherents amongst NorthAmerican music theorists. Also, I will consider the analyses I discuss in relative abstraction from the theoretical positions that partly motivate them, and I will occasionally describe early analyses in terms foreign to their authors. If my procedure makes for questionable intellectual history, it is nonetheless germane to my present aim, which is to argue that Hauptmann's text suggests an

1 As the bibliography of Tristan-chord analyses appended to this article amply attests.

2 Hauptman $(1853 ; 1888)$. Subsequent references to Hauptmann will be made parenthetically with page numbers from the German edition followed by page numbers from the translation. 

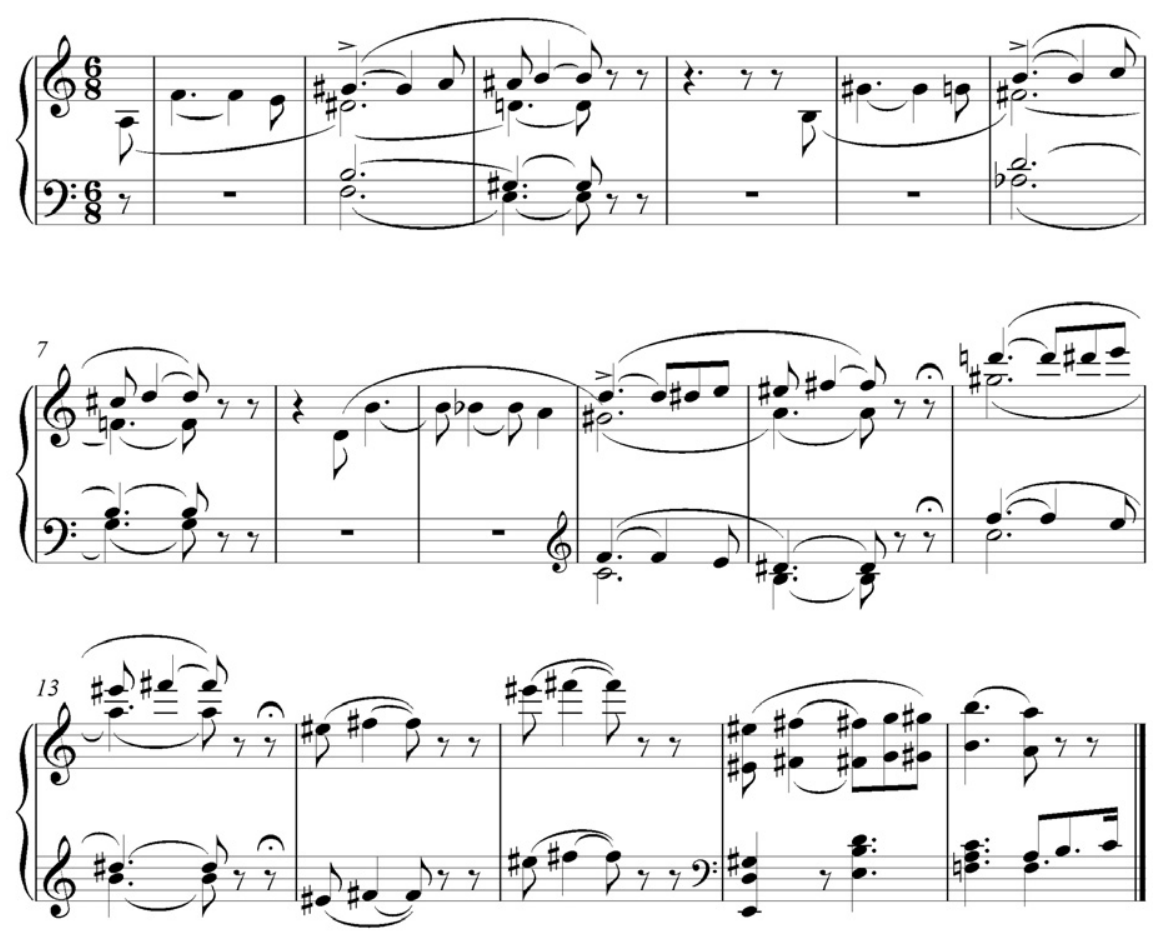

Example 1: Tristan Prelude, mm. 1-17.

interpretation of the Tristan chord that is compelling from the perspective of current American music theory.

It is heuristically useful, though no doubt artificially neat, to group explanations of the Tristan chord into five broad families. These five classes variously take the Tristan chord as (1) a functional half-diminished seventh chord, (2) a minor triad with added sixth, (3) some sort of "pre-dominant" sonority, (4) a dominant-functioned harmony, and (5) a sonority that cannot be analyzed in tonal terms.

1. The basic analytical problem posed by the Tristan chord, as Jean-Jacques Nattiez (1985) has succinctly observed, is that the harmonic progression in measures 2-3 of the Tristan Prelude corresponds to none of the successions typically classified in harmony texts. The structure of the chord itself is not necessarily problematic: the chord may be readily described as either a half-diminished seventh chord built on F or as a $\mathrm{G} \#$ minor triad with added sixth (enharmonically spelled in either case). The difficulty lies rather in explaining how and why this chord resolves to $\mathrm{E}^{7}$ on the downbeat of measure 3. Normally, the chord found in meaure 2 would appear as $\mathrm{ii}^{\varnothing 7}$ of $\mathrm{E} b$ minor (spelled $\mathrm{F}-\mathrm{A} b-\mathrm{C} b-\mathrm{E} b$ ) or as vii ${ }^{ø 7}$ of $F \#$ major ( $\left.E \#-G \#-B-D \#\right)$. That the enharmonic equivalence of the Tristan chord to the former is relevant in the Prelude is clear from example 2. In this passage, measures $81-82$ of the Prelude, the chord twice moves to $\mathrm{V}^{7}$ of $\mathrm{B} b$ before being deflected to $\mathrm{E}^{7}$ in measure 84 (ex. 2). In his Harmonielehre, 

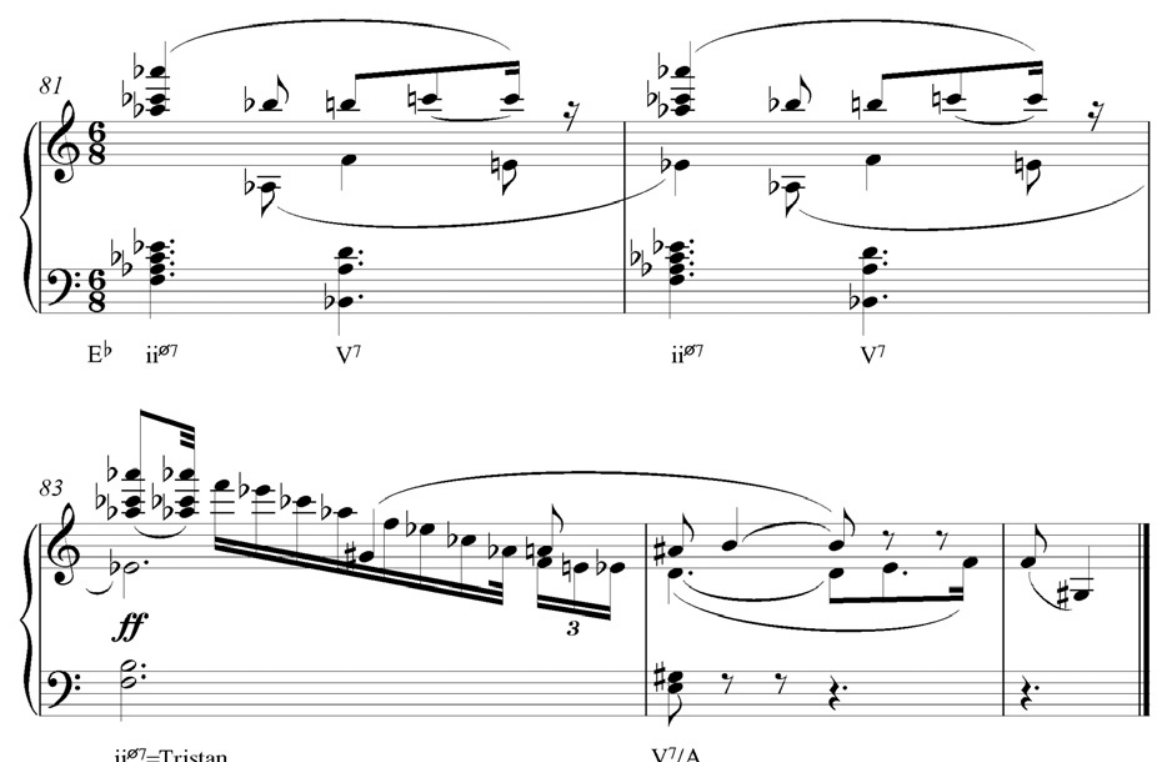

Example 2: Tristan Prelude, mm. 81-84

Schoenberg flirted with analyzing the Tristan chord in measure 2 analogously as $\mathrm{ii}^{\varnothing 7}$ of $\mathrm{E} b$, an interpretation that has been revived more recently by Dieter Gostomsky (Schoenberg 1978; Gostomsky 1975).

The second possibility-that the chord is vii ${ }^{87}$ of $\mathrm{F}^{\sharp}$-has recently been endorsed by Richard Bass (1996), though in a highly qualified sense. Bass notes that the Prelude's first and second phrases are near-exact transpositions of one another; the third phrase, however, is significantly altered so as to arrive on the dominant of $\mathrm{E}$ (rather than that of $\mathrm{E}$ ) in measure 11. Example 3 freely reproduces Bass's hypothetical recomposition of the first eleven measures of the Prelude, in which measures 8-11 become an exact transposition of measures 4-7. Example 4, incidentally, gives measures 83-90 of the Prelude, where the progression shown in measures 8-11 of Bass's recomposition is partially realized. 3 To make Bass's point clearer, I have added a fourth iteration of the sequence at the end of example $3(\mathrm{~mm} .12-15)$. If these final measures are in turn transposed up a minor third, the result will be measures $1-3$. The crucial point here is that the end of example 3 relates back to the beginning in the same way that each previous phrase relates to its successor. Since the cycle ends on V7 of $\mathrm{F} \#$, the Tristan chord in measure 2 hints at vii ${ }^{\varnothing 7}$ of $\mathrm{F} \#$.

2. The other "obvious" description of the Tristan chord takes it as a G\# minor triad with added sixth. The most prominent recent advocate of this interpretation is Robert Bailey (1985), who favours this analysis in large part because it

3 Measures 83-90 of the Prelude (see ex. 4) correspond to the sequence shown in example 3 up to the half bar of measure 89 , where Wagner breaks off by leading the lower three voices downward by a semitone to form a French augmented-sixth chord on $\mathrm{B}$, which then resolves to $\mathrm{A}^{7}$ in measure 90. 

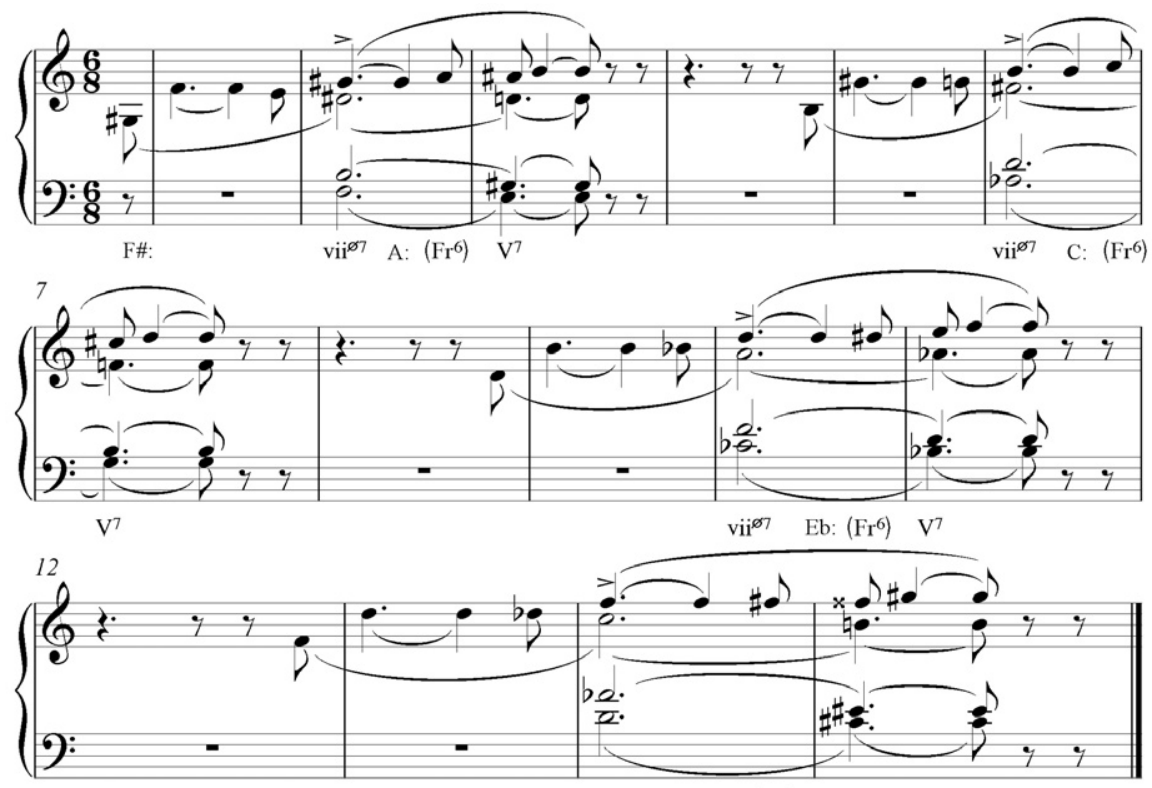

Example 3: Bass's Recomposition of mm. 1-11

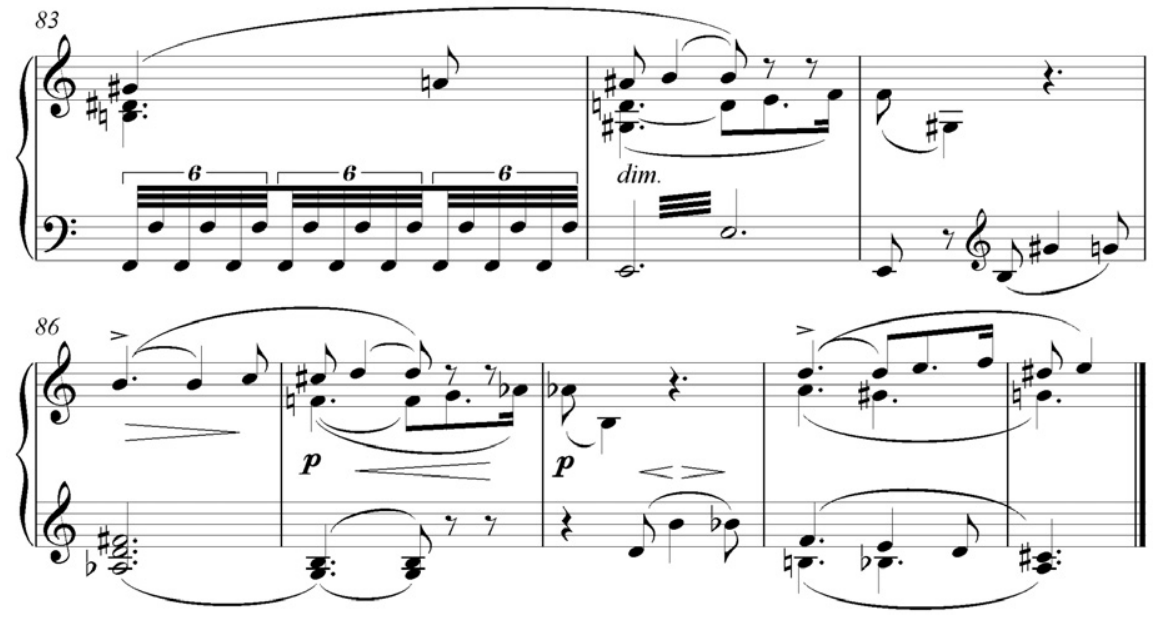

Example 4: Tristan Prelude, mm. 83-90

plays into his more general theoretical argument about the tonal language of Tristan. For Bailey, the first act of the opera presents a "double-tonic complex" in which $\mathrm{A}$ and $\mathrm{C}$ act as interchangeable forms of the tonic. The "harmonic embodiment" of this double-tonic complex is the chord C-E-G-A. The Tristan chord is understood by analogy as a kind of "minor version" of this same chord ( $\mathrm{E} b$ replaces $\mathrm{E}$ and the entire chord is transposed down a major third). Bailey cites two passages from elsewhere in Tristan in support of his interpretation. 
Example 5, which comes from the end of act 1, gives the first. Here, the opening two statements of the Prelude are freely recapitulated but with first-inversion $\mathrm{A} b$ major and $\mathrm{B}$ major triads respectively standing in for the original Tristan chords. The second passage, given in example 6, is from the opening of the Prelude to act 3. In this passage, the Tristan chord appears as a Bb minor triad with added sixth resolving to F minor.

Bailey's analysis is highly intriguing in the link that it suggests between the Tristan chord and the broader tonal articulations of the opera (particularly given the prominence of $\mathrm{A} b$ and $\mathrm{B}$ major in acts 2 and 3 ). But as an analysis of the local progression in measures 2-3 of the Prelude, it is unsatisfactory. Indeed, the overarching problem with all of the interpretations discussed thus far is that none of them can explain what so foreign a chord is doing in a passage that, for most analysts, is more or less unequivocally in A minor. ${ }^{4}$ In order to do so, both Bailey and Bass fall back on what was once the preferred explanation of the chord in North America: namely as a French augmented-sixth chord (F-A$\mathrm{B}-\mathrm{D} \#$ ) disguised by a long $\mathrm{G} \#$ appoggiatura. ${ }^{5}$

3. The analysis of the Tristan chord as a French sixth is ubiquitous in the English-language literature (inter alia: Cone 1962; DeVoto 1995; Hill 1984). An adequate discussion of this particular interpretation would require a lengthy digression on early-twentieth-century German harmonic theory-one passing, notably, through Carl Mayrberger (1881), Max Arend (1901), Ernst Kurth (1923) and Alfred Lorenz (1926). In the interest of brevity, I propose to excuse myself from surveying this well-travelled terrain. ${ }^{6}$ Let me note in passing, though, that John Rothgeb's recent analysis of the Tristan chord is best seen as a refinement of the French-sixth interpretation. For Rothgeb (1995), while the G\# is a non-chord tone, it is not an appoggiatura. Rather, as shown in example 7, the G\# in measure 2 is a part of the $\mathrm{E}^{7}$ chord in measure 3 that has entered prematurely.

The appeal of analyzing the Tristan chord as a French sixth lies in the attempt to subsume the opening of Tristan under the rubric of a recognizable harmonic progression, and to do so, moreover, in a way that preserves the intuition that these measures represent a progression from pre-dominant to dominant harmonies. A significant shortcoming, however, is that, in order to do so, the interpretation must explain-or indeed explain away-the $G \#$ in measure 2 as a non-chord tone. I find it frankly impossible to hear this note as an appoggiatura and am inclined to think that this is a reason good enough to question any analysis that commands me to do so. But there are also larger-scale analytic reasons to take $\mathrm{G} \#$ as part of the Tristan chord. It is customary, first of

4 For a dissenting view, according to which the entire Prelude is in C major, see Burstein (1983).

5 Bailey's discussion is revealing: "We could argue that an inherent beauty of music is that it can in fact do two things at the same time, and this may well be so in the present instance. Thus, we have a striking example of two different but equally appropriate interpretations: $8 \mathrm{~b}$ [which analyzes the chord as a French sixth] deals with the situation as a purely local event, while 8a [which gives Bailey's preferred analysis of the chord as a $\mathrm{G} \sharp$ minor triad with added sixth] takes into account the chord's large-scale structural implications" $(1985,124)$. Bass, for his part, places the label "Fr" in parentheses under the sixth beat of measure 2 in his reconstruction (283). I have reproduced his labelling in my example 3 .

6 Readers wanting a thorough overview should consult Vogel (1962). 


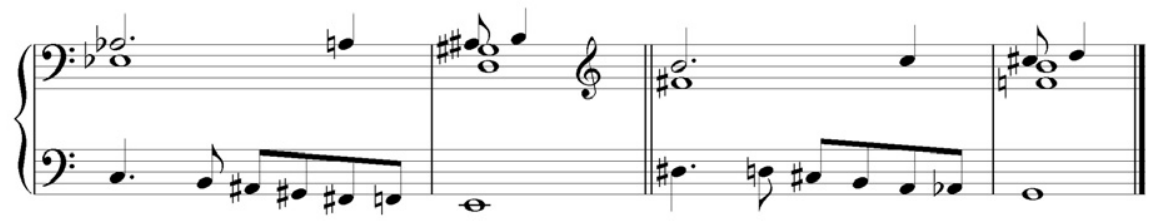

Example 5: Tristan, Act I, scene 5, mm. 504-505, 511-512

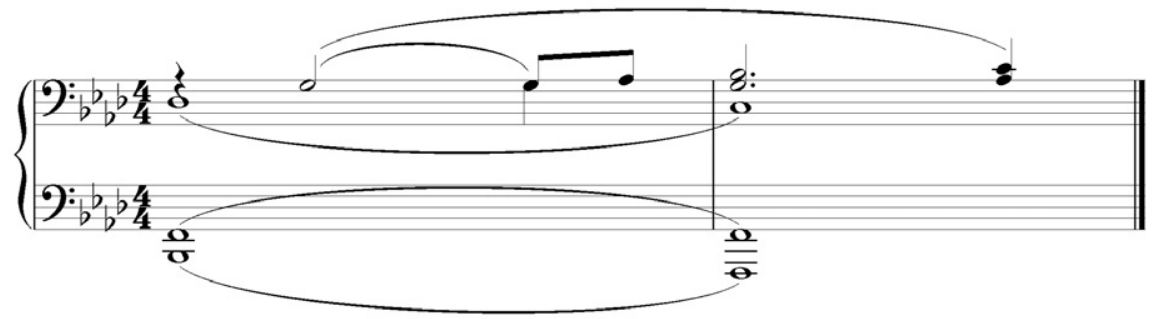

Eample 6: Tristan, Act III Prelude, mm. 1-2

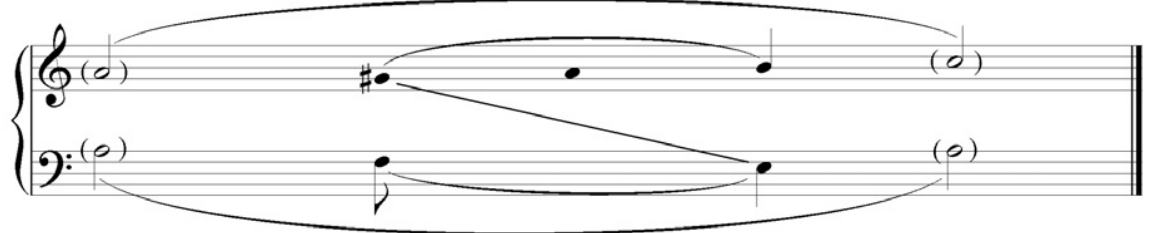

Example 7: Rothgeb's Analysis of mm. 1-3

all, to see a voice exchange ( $G \#$ for $B$ and vice versa) between the soprano and tenor parts in measures $2-3$. Second, the soprano line in measures $1-11-G \mathbb{G}-B$, $\mathrm{B}-\mathrm{D}, \mathrm{D}-\mathrm{F} \#$-outlines the Tristan chord as it appears vertically in measure 6. If the $\mathrm{G} \#$ is really an appoggiatura to $A$, then both claims must be abandoned.

4. In his 1967 analysis of the Tristan Prelude, William Mitchell advanced both of these arguments against the French-sixth interpretation. His own favoured analysis reduces the Tristan chord instead to the fully diminished seventh chord F-G\#-B-D. On Mitchell's reading, that is, $G \#$ is not an appoggiatura, but $\mathrm{D} \#$ is. And it is worth emphasizing just how unorthodox this analysis is: in measures $2-3$ of Tristan, $\mathrm{D} \#$ does not resolve to $\mathrm{D}$ over the same bass note (Kirnberger's criterion for distinguishing between essential and inessential dissonances 7 ); rather, $\mathrm{D}$ enters together with the new bass note $\mathrm{E}$. The primary argument that Mitchell advances in favour of his analysis involves a comparison of the Prelude's opening to the passage given in example 8a. In measures 66 and 68 of the latter passage, D natural substitutes for the Tristan chord's original $D \#$. Mitchell infers that this second passage reveals the underlying harmonic structure of the Prelude's opening. But one need not draw that conclusion. 
In measure 66, the (modified) Tristan chord enters as part of a long dominant prolongation. Here, as vii ${ }_{2}^{4}$ of A minor, the chord acts as a fleeting embellishment of $\mathrm{V}^{7}$. This use of the chord is exactly parallel to that seen in measures 8-9 of example 8b, a passage from the introduction to the Pathétique Sonata that Mitchell cites in support of his interpretation. Yet nothing in examples $8 \mathrm{a}$ or $8 \mathrm{~b}$ implies that the Tristan chord in measure 2 is really viio4. One could just as easily argue that the Prelude's opening gives the basic form of the progression and example 8a the variant. First of all, when the second and third phrases of the opening are recapitulated in the continuation of the passage, the original chords are retained. ${ }^{8}$ Moreover, Mitchell's own analysis offers a good explanation for Wagner's decision to alter the first phrase, namely the retention of $\mathrm{d}^{3}$ as an upper neighbour to the Prelude's head-tone from measure 53 to measure 77.

Mitchell might also have cited the passage given in example 9a, in which the opening material of the Prelude cycles back for a final time. ${ }^{9}$ In fact, his analysis is most convincing when applied to these measures. The Tristan chord occurs at its original transposition in measure 102. In measure 103, however, $\mathrm{F}$ is retained in the bass rather than resolving to $\mathrm{E}$ as it did before. The alto's $\mathrm{D} \#$, now written $\mathrm{E} b$, moves to $\mathrm{D}$ over a single bass note, and the resulting fully diminished-seventh chord, reinterpreted as vii ${ }_{3} 4$ of $\mathrm{C}$ in turn points toward the opening key of act 1 . The use of the Tristan chord here is identical to that found in example 9 b, a passage from the first movement Beethoven's Sonata, op. 31, no. 3 that is frequently (and in my view mistakenly) cited as an anticipation of the opening of Tristan. In both passages, the $\mathrm{E} b$ in the alto can reasonably be analyzed as an appoggiatura to $\mathrm{D}$ and the underlying chord thus identified as $\mathrm{F}-\mathrm{A} b-\mathrm{B}-\mathrm{D}$. The difference between this progression and the one that opens the Prelude, however, is immediately apparent to the ear if the two passages are juxtaposed.

Our analyses of examples $8 \mathrm{a}$ and $9 \mathrm{a}$, I have been trying to show, need not lead us to adopt the same analysis for the Prelude's opening. And there is a further reason to avoid doing so. Analyzing the Tristan chord in measure 2 as viio4 $_{2}$ of A minor, as Mitchell does, means asserting that there is effectively no harmonic progression between measures 2 and $3 .{ }^{10} \mathrm{I}$ find this analysis compelling for examples $8 \mathrm{a}$ and $9 \mathrm{a}$ but deeply counterintuitive for the opening of

8 Measures 70-71 of the Prelude (ex. 8a) correspond to measures 6-7 (ex. 1), though with the chords revoiced so that the original outer-voice pair ( $A$ b falling to $\mathrm{G}$ against $\mathrm{B}$ rising through $\mathrm{C}$ and $\mathrm{C}^{\sharp}$ toD) appears in the lower voices. Measures $72-73$ likewise correspond to 10-11, though in this case the original chord C-F-G $G^{\sharp}-\mathrm{D}$ is not literally sounded as a single verticality: the $\mathrm{G}^{\sharp}$ is delayed by an A appoggiatura, and by the time that appoggiatura resolves, $\mathrm{D}$ has pressed on to $\mathrm{D}^{\sharp}$.

9 He does not because he is analyzing the concert version of the Prelude, in which the relevant measures do not appear.

10 An even more extreme reading has been proposed by Jacques Chailley $(1963,24,32)$, who literally replaces the Tristan chord in measure 2 with V7 of A minor in his harmonic reduction of the Prelude. The (unstated) theoretical justification for Chailley's analysis may come from Louis and Thuille's Harmonielehre (1928, 230-232), where the chord F-G\#-B-D\# is analyzed as a leading-tone seventh chord on $\mathrm{G}^{\sharp}$ with a raised fifth. Louis and Thuille reject this analysis for the opening measures of Tristan, however, because they wish to assign subdominant rather than dominant function to the Tristan chord in this context. (To do so, they interpret the $\mathrm{G}^{\sharp}$ as an appoggiatura to $\mathrm{A}$, and so read a French-sixth chord, as in Bailey's analysis discussed above.) 

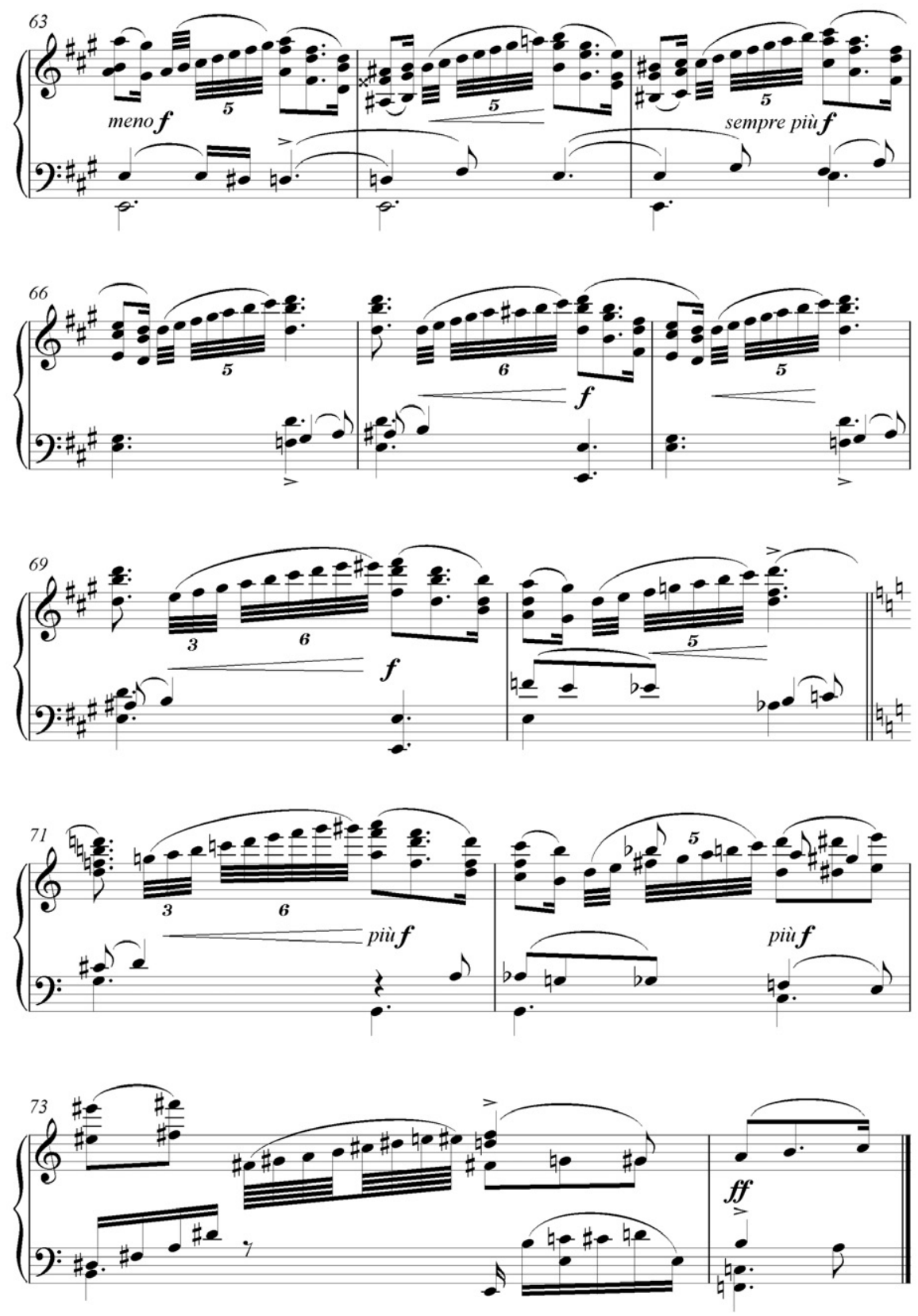

Example 8a: Tristan Prelude, mm. 63-74 

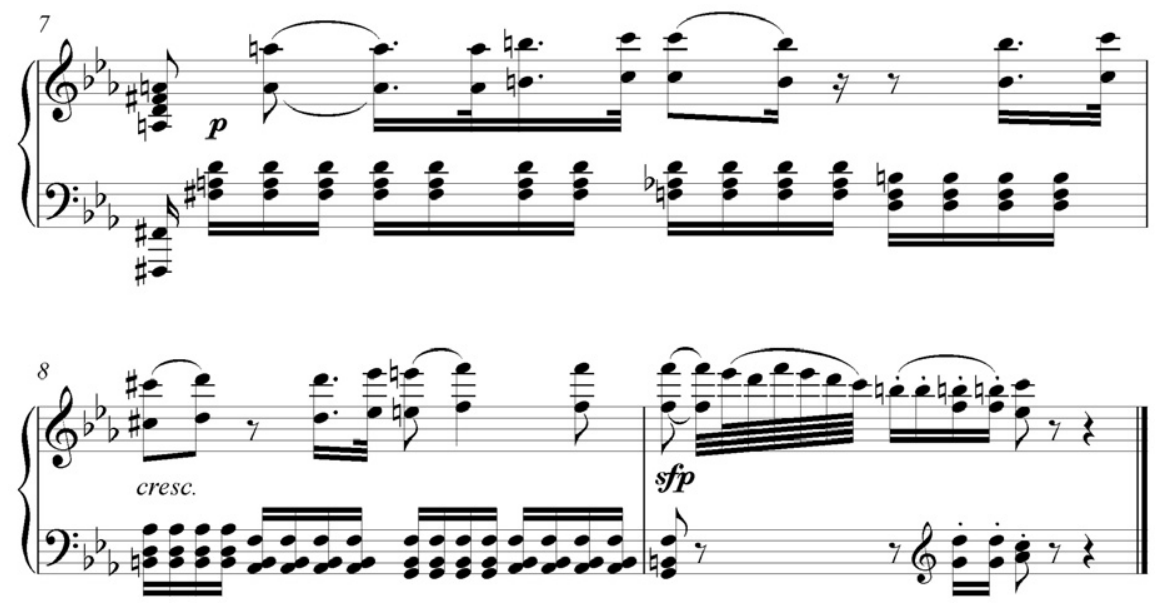

Example 8b: Beethoven, Sonata, Op. 13, I, mm. 7-9

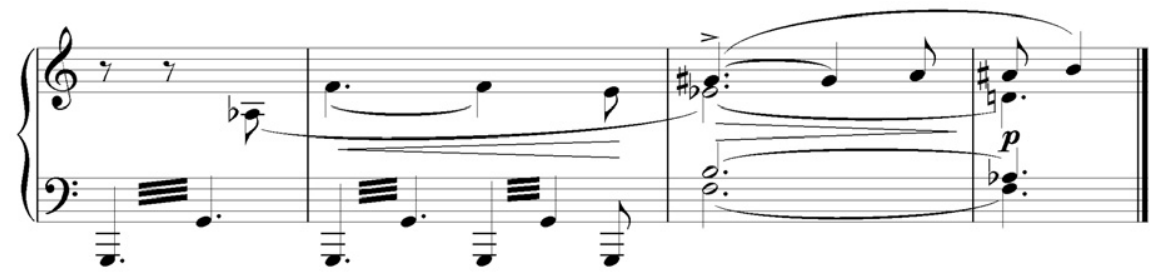

Example 9a: Tristan Prelude, mm. 100-103
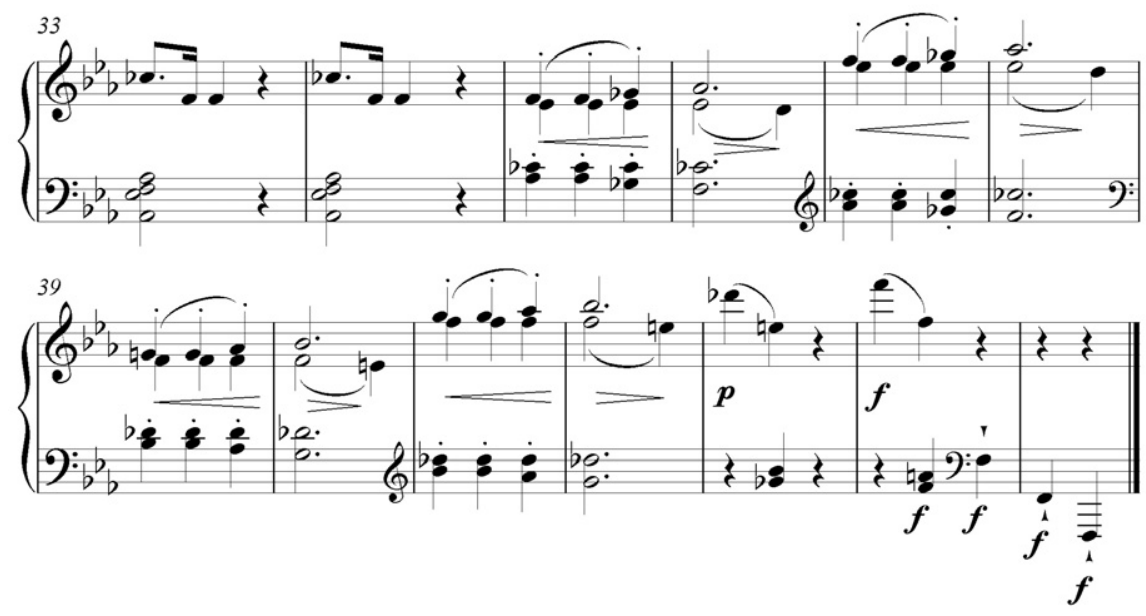

Example 9b: Beethoven, Sonata, Op. 31, No. 3, I, mm. 33-45 
the Prelude. The strength of the French-sixth interpretation, after all, was to preserve the sense that measures 2-3 present a real harmonic progressionone that moves from pre-dominant to dominant harmony; its weakness was to treat the $\mathrm{G} \#$ as a non-chord tone. Mitchell's explanation does just the opposite: it accepts $\mathrm{G} \#$ as chordal but implies that there is effectively no harmonic progression between the second and third measures.

5. A final prevalent attitude towards the Tristan chord holds that tonal theory does not provide an adequate framework for its explanation. As Milton Babbitt (1976), Benjamin Boretz (1972), and Allen Forte (1988) have emphasized, the Tristan chord in measure 2 is the mirror inversion of the $\mathrm{E}^{7}$ chord that follows it. David Lewin (1996) and Robert Gauldin (2001) describe the progression in terms indebted to neo-Riemannian theory. ${ }^{11}$ Both cite unpublished work by Jack Douthett that generalizes Richard Cohn's (1996) work on hexatonic cycles. In his 1996 article, Cohn discussed progressions between triads in which two pitches are retained while the third moves by semitone (e.g., $\mathrm{C}$ major to E minor). Lewin terms this relationship a "Douthett relation of degree 1" (DOUTH1). One generalization proposed by Douthett treats progressions between tetrachords of the same set class in which two pitches are retained while two move by semitone (the DOUTH 2 relation). Lewin illustrates his discussion by applying the DOUTH2 relation to the Tristan chord. Example 10 shows all possible successions in which the Tristan chord moves to another half-diminished or major-minor seventh chord by semitone voice leading involving exactly two pitches.

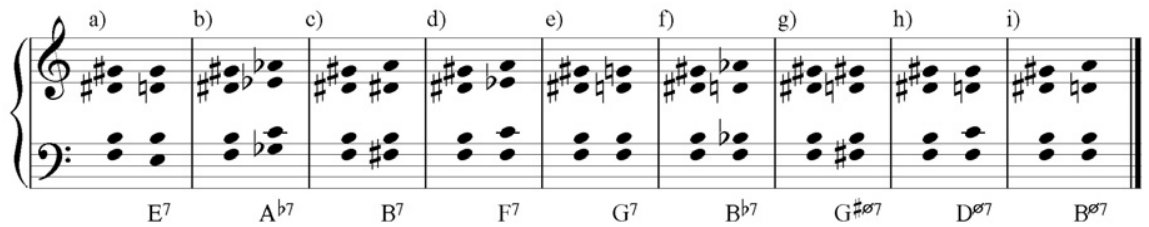

Example 10: DOUTH2 Relation Applied to the Tristan Chord

The DOUTH2 relation essentially brackets out questions of tonality and harmonic function. This is not a criticism per se. Indeed, Douthett's work, particularly as Robert Gauldin has employed it, seems to offer one of the most promising frameworks available for understanding the general behaviour of the Tristan chord throughout Wagner's opera. That said, as example 10 illustrates, some of the progressions described by $\mathrm{DOUTH}_{2}$ are familiar tonal progressions. Others are more exotic, and some perhaps defy tonal classification altogether. The relevant question here, a question the DOUTH2 relation leaves entirely open, is this: into which of these three classes does the opening progression of Tristan fall?

The time has come to turn at last to Hauptmann. The relevant passage, $\$ 141$ of Die Natur der Harmonik und der Metrik, comes in the course of a general discussion of the possible resolutions of seventh chords. Hauptmann develops

11 See also Gollin (1998) and Tymoczko (2008). 
his account by analogy with his earlier treatment of suspensions. The suspension, Hauptmann has maintained, is a particular dissonance that occurs when two notes that are normally presented in succession are sounded simultaneously (Hauptmann 1853, 74-75, 86-89; trans., 54, 65-67). ${ }^{12}$ In general, Hauptmann regards the phenomenon of dissonance as the audible expression of a conflict of meaning. In this case, the conflict inheres not in the two pitches comprising the dissonant interval but rather in a third pitch to which both are related. If, to take the example given in figure $1, F$ sounds against $G$, the dissonant effect arises from the differing ways in which $\mathrm{F}$ and $\mathrm{G}$ are related to $\mathrm{C}$. On the one hand, C is the fifth of F; on the other, it is the root of G. C is thus simultaneously imbued with two conflicting harmonic meanings: it is at once root and fifth. The resolution of the dissonance occurs when this conflict is resolved. When $\mathrm{F}$ moves to e, the status of $\mathrm{C}$ as fifth is cancelled: $\mathrm{C}$ now carries root meaning with respect to both e and G. ${ }^{13}$

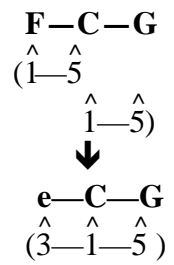

Figure 1: Hauptmann's analysis of the suspension

Hauptmann's treatment of seventh chords is strictly parallel to his handling of suspensions. Unlike Rameau, Hauptmann does not regard seventh chords as triads with added notes. Instead, he sees them as superpositions of triads. Hauptmann has previously insisted that in any allowable progression between two triads exactly one pitch of the first moves by step in order to produce the second (Hauptmann 1853, 64-74; trans., 45-53). Progressions in which two or even three notes appear to move are in fact elided expressions of motions that satisfy this condition. For instance, the progression of C-e-G to b-D-G is an abbreviated form of that from C-e-G through b-e-G to b-D-G (fig. 2). If the first and second or second and third triads in this progression are played simultaneously, the seventh chords C-e-G-b and e-G-b-D will result. Like suspensions, then, seventh chords result from the superposition of elements that are normally presented successively, and, like suspensions, their dissonant effect results from a conflict of meaning. Here, though, the locus of that conflict is the internal interval of the chord. The extreme notes, e and $\mathrm{D}$, of the $\mathrm{E}^{7}$ chord given in figure 3 stand in no harmonic relation to one another. ${ }^{14}$ Both extremes,

12 For a general introduction to Hauptmann, see Harrison (1994). On Hauptmann's handling of the suspension in particular, see Caplin (1984).

13 I adopt Hauptmann's notational conventions regarding upper- and lower-case letters for pitch names: thirds that join an upper-case letter to a lower-case one are acoustically pure (i.e., 4:5 or 5:6), those that link two upper-case or two-lower case letters are not.

14 For Hauptmann, only the major third and perfect fifth are "directly intelligible" intervals (21-22; trans., 5-6). 


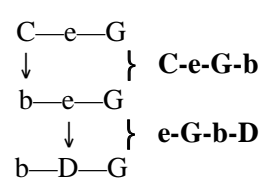

Figure 2: Hauptmann's construction of seventh chords

a)

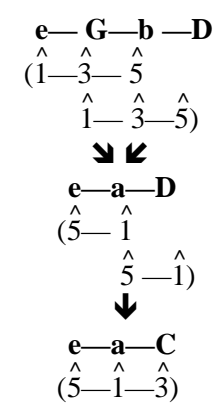

b)

OR

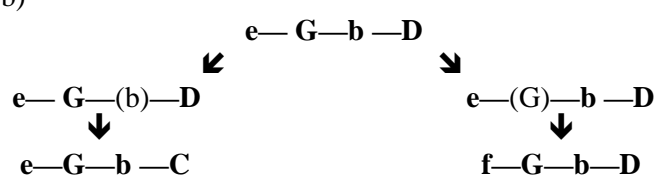

c)

OR

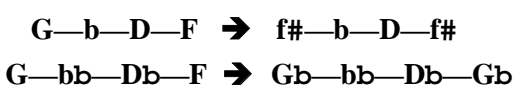

Figure 3: Three resolutions of the seventh chord

however, are related to the internal interval of the seventh chord, G-b: e is the root of G-b, while D is its fifth: G-b is thus simultaneously third and fifth (of e) and root and third (of D).

Hauptmann considers three ways in which this conflict can be resolved. The first possibility, shown in figure $3 \mathrm{a}$, involves two steps. The internal interval G-b moves to a, and the problem of the chord's resolution is thus reduced to the resolution of the suspension e-D. A second possibility, figure $3 \mathrm{~b}$, involves ignoring one note of the chord's internal interval and resolving the chord with respect to the other. The result is a succession of seventh chords.

The resolution of interest here, though, is the third and final possibility. In this case, the internal interval stays fixed and both of the extremes move outward by semitone. Figure $3 \mathrm{c}$ shows Hauptmann's examples. The first presents a $\mathrm{G}^{7}$ chord resolving, as though it were a German sixth, to a cadential 6-4 in 
B minor. The second shows a half-diminished seventh chord on $G$ resolving analogously to a $\mathrm{G} b$ major triad. Hauptmann's description runs as follows:

141. This is the resolution in which the minor Seventh is expanded to the octave by a diverging progression in the outer parts. The middle interval, which remains stationary, must stand in a consonant relation to the octave: e.g.,

$$
\text { G-b-D-F ... f } \sharp-b-D-d \#
$$

or

$$
\mathrm{G}-\mathrm{b} b-\mathrm{D} b-\mathrm{F} \ldots \mathrm{G} b-\mathrm{b} b-\mathrm{D} b-\mathrm{G} b
$$

This resolution can therefore occur only when the chord's seventh is minor and the diminished triad is part of the chord. Only in this way can the conditions required for this resolution be met. It should also be noted that the resolution here leads to another key, since this resolution is possible only through a chromatic progression in one of the two parts, and chromatically differentiated notes never lie in the same key.15

Transposed down a tone, this second progression is essentially identical to that in measures $2-3$ of Tristan. ${ }^{16}$ What I find particularly suggestive in Hauptmann's juxtaposition of the two progressions is the implicit suggestion that the half-diminished seventh chord is, in this use, a type of augmentedsixth chord.

Of course, Hauptmann did not mean to describe the opening of Wagner's Prelude in $\$ 141$ of his text—-the chronology alone makes that impossible. But there is also a salient difference between the progression he describes and the one that opens Tristan. For Hauptmann, each of the resolutions described in $\$ 141$ necessarily involves a modulation. In Hauptmann's view, the motion from the cadential seventh of $\mathrm{C}$ major to the dominant 6-4 of $\mathrm{B}$ minor (G-b-D$\mathrm{F} \rightarrow \mathrm{f} \#-\mathrm{b}-\mathrm{D}-\mathrm{f} \#$, in his notation) is fundamentally different from the resolution, within B minor, of the German augmented-sixth on $G$ to the cadential 6-4 of $\mathrm{F} \#$ (g-B-d-E\#-F\#-b-d-F\#). An analogous requirement holds for the parallel case in which the half-diminished seventh chord on $G$ resolves like an augmented sixth to Gb major. Indeed, for Hauptmann, this resolution occurs only in modulating passages: when augmented-sixth chords are discussed in more detail at $\$ \$ 220-223$, Hauptmann explicitly forbids this resolution as a harmonic progression within a single key.

15 "141. Es ist dies diejenige Auflösung, bei der das Intervall der kleinen Septime durch Fortbewegung beider Stimmen sich zur Octav erweitert, zu welcher das bleibende mittlere Intervall in consonantem Verhältnisse stehen muss, z. B. G-h-D-F. . fis-h-D-fis; oder $g-B$-des-F...Ges-b-Des-Ges. Diese Auflösung kann eben nur bei Dissonanzaccorden mit kleiner Septime, an denen der verminderte Dreiklang Theil hat, vorkommen, indem diese nur die Bedingungen der Auflösung erfüllen können. Zudem ist auch noch zu bemerken, dass die Auflösung hier in eine andere Tonart führt, indem sie nur durch chromatische Fortschreitung einer der beiden Stimmen geschehen kann; chromatisch verschiedene Töne aber nie innerhalb derselben Tonart liegen" (Hauptmann 1853, 94; my translation).

16 Of course, in the Prelude the upper note of the augmented sixth ( $\left.D^{\sharp}\right)$ moves down to D rather than up to E. But this detail is of little concern: just as the leading tone of a dominant seventh may resolve downward by semitone when the chord is followed by another dominant seventh, the "leading tone" of the Tristan chord moves to the seventh, rather than the root, of the following E7 chord. 


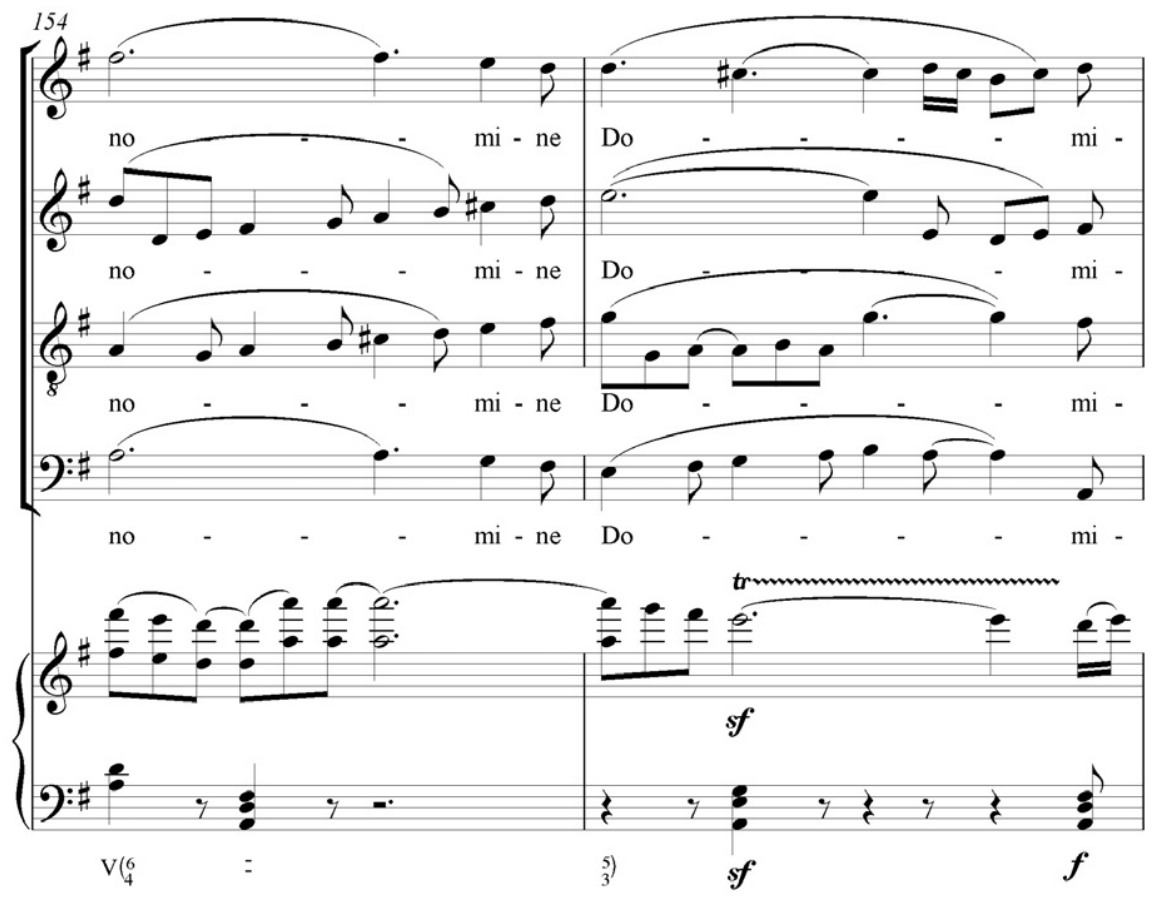

Example 11: Beethoven, Missa solemnis, Benedictus, mm. 154-59

For Hauptmann, augmented-sixths result when the extremes of a shifted minor key are sounded as a single sonority (Hauptman 1853, 147-154; trans., 120-126). Minor keys, like major keys, are systems consisting of a tonic flanked by its subdominant and dominant (Hauptmann 1853, 35-39; trans., 17-21). C minor, for instance, is the system F-ab-C-eb-G-b-D. Without disrupting the key, this system may be shifted one place to the right as follows: $a b-C-e b-G-$ b-D-f\# (Hauptmann 1853, 46-52; trans., 28-30). Augmented-sixth chords result when the extremes of the shifted minor system are brought together. The three chords that result from this process are the French sixth (D-f $\sharp \mid a b-c)$, the German sixth ( $f \sharp \mid a b-C-e b)$ and the Tristan chord (b-D-f\#| ab). In \$230, however, Hauptmann dismisses the last: both $\mathrm{b}$ and $\mathrm{f} \#$ are leading tones, he maintains, but $\mathrm{b}$ is only a leading tone in relation to $\mathrm{F}$ and $\mathrm{f}$ only in relation to $\mathrm{C}$. In the chord in question, though, $\mathrm{b}$ replaces $\mathrm{C}$ and $\mathrm{f}$ replaces $\mathrm{F}$. The chord thus contains an "inner contradiction" and so must be set aside.

On Hauptmann's account, the half-diminished seventh chord can therefore resolve like an augmented sixth only in the course of a modulation between keys. The situation that he likely has in mind is the one shown in example 11. Here, in measures 154-159 of the Benedictus from Beethoven's Missa Solemnis,

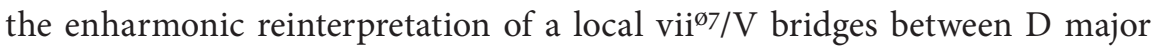
and G. In measure 156, V7 moves to vi, delaying the expected cadence on the tonic. The bass then drops to $\mathrm{G} \#$ to form vii ${ }^{\varnothing 7} / \mathrm{V}$ (which projects a return to the cadential dominant). Instead of moving through $V^{7}$ to I, however, so as to grant 


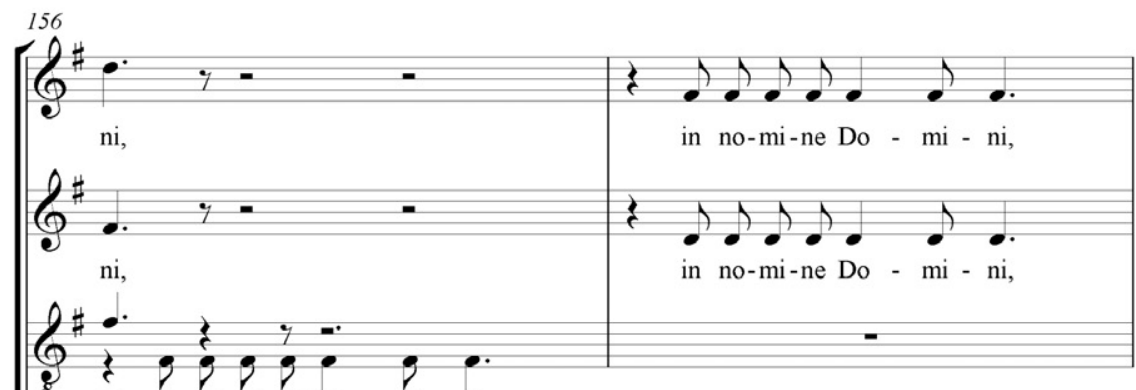

ni, in no-mi-ne Do - mi - ni,
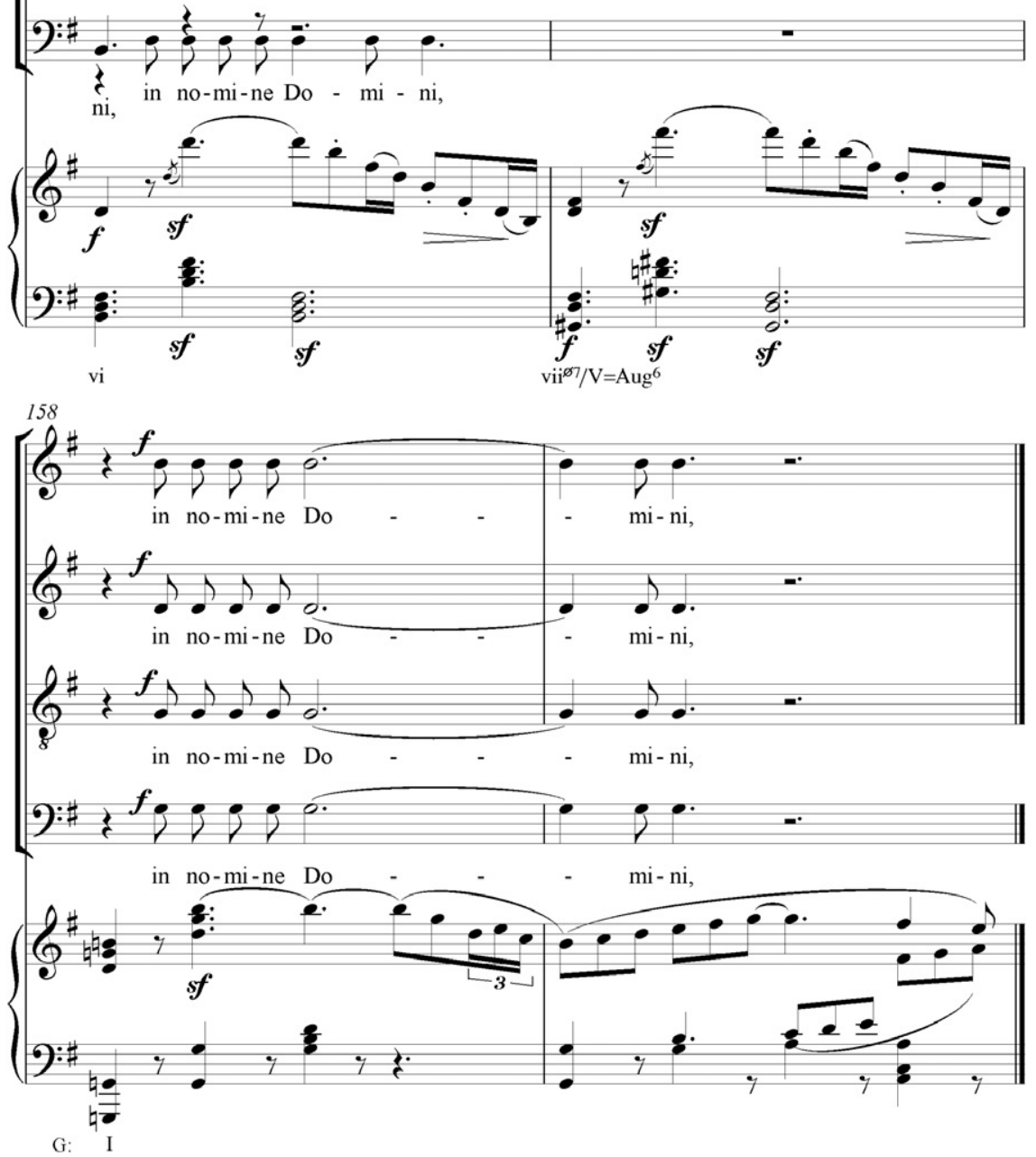

Example 11: (continued) 


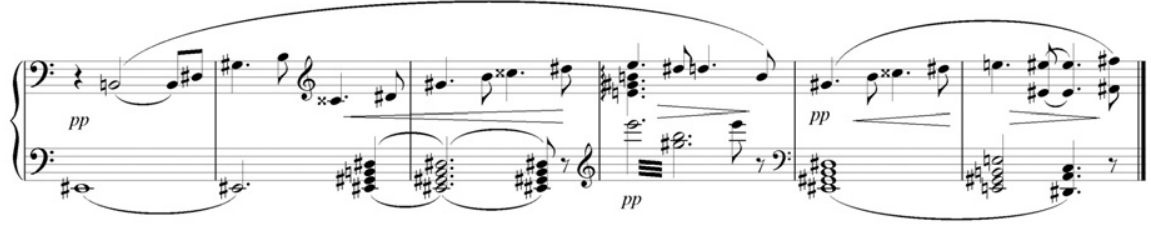

Example 12: Wagner, Parsifal, Act 2

the cadence expected from at least measure 154, the outer pitches of the vii ${ }^{\varnothing 7 / \mathrm{V}}$ chord in measure 157 ( $G \#$ in the bass and $F \#$ in the soprano) move outward by step to reach a $\mathrm{G}$ major triad in measure 158. In this instance, the resolution of a half-diminished seventh chord as a kind of augmented sixth (here with dominant rather than subdominant function) effects a modulation from the tonic key to its subdominant.

There is, however, no compelling reason to adopt Hauptmann's restriction on the resolution of the half-diminished seventh chord as an augmented sixth. No systematic considerations compel him to reject the progression as an allowable succession within a single key, and the reasons that he ends up advancing are ad hoc and unconvincing. Finally, we-unlike Hauptmann-can invoke a paradigmatic instance: namely, the opening progression of Wagner's Tristan und Isolde. ${ }^{17}$

Hauptmann's text therefore suggests the following analysis of the Tristan chord's behaviour in measure 2 of Wagner's Prelude: the chord is a half-diminished seventh chord enharmonically reinterpreted to function as an augmented sixth. To return to my earlier paraphrase of Nattiez, the opening progression of the Tristan Prelude corresponds to none of the progressions classified by textbook harmony: the augmented-sixth chord in measure 2 is not French, or German, or Italian. Nattiez concluded that any analysis of these measures must consequently alter the Tristan chord in some way so as to make its resolution conform to some standard progression. But in fact there is another option available: we can simply admit an additional category of augmented-sixth chord.

This theoretical conclusion, together with the analysis of the Tristan chord that it permits, will already be familiar to readers of Daniel Harrison's (1995) article on augmented-sixth chords. What I have hoped to contribute is a previously unnoticed precedent for Harrison's analysis, together with some additional arguments in favour of its adoption.

Let me briefly recapitulate these arguments. The analysis of the Tristan chord presented here incorporates the three desiderata that emerged from my initial survey: (1) the Tristan chord consists of the notes F-G\#-B-D\#; (2) the progression in measures $2-3$ of the Prelude is a functional harmonic

17 Interestingly enough, Wagner may have owned a copy of Hauptmann's text. While visiting Wahnfried during the summer of 2003, I noticed a copy of Die Natur der Harmonik und der Metrik among the books preserved in the main-floor Wohnzimmer. Staff at the Richard Wagner Museum Bayreuth have not, however, been able to confirm that the volume belonged to Wagner. 
progression ${ }^{18}$ - one that moves (3) from pre-dominant to dominant harmony. ${ }^{19}$

The theoretical conclusion that this analysis entails may well be thought contentious. After all, pluralitas non est ponenda sine necessitate, and to invent a new category of augmented-sixth chord to cover just one instance would indeed be extreme. But luckily, the progression is not unique to Tristan und Isolde. Wagner himself employs it not infrequently in his post-Tristan worksthe most famous example being "Kundry's kiss" in the second act of Parsifal (ex. 12). In Ernest Chausson's Le Roi Arthus, the progression figures prominently in act 3, when Geneviève strangles herself with her hair (ex. 13). Richard Strauss inserts it into act 1 of Der Rosenkavalier as a kind of musical wink to accompany Octavian's (inadvertent) parody of Tristan's language ("Was heißt das 'Du'? Was 'Du und ich'? Hat denn das einen Sinn? . . . das Ich vergeht in dem Du"; ex. 14). More enigmatically, Strauss also quotes it near the end of Til Eulenspiegel (ex. 15). ${ }^{20}$

A more exhaustive survey of the late-nineteenth-century repertory would no doubt turn up more examples, perhaps some of them in contexts less obviously evocative of Wagner. As for whether the progression ever appears in

18 A "harmonic" progression, in the sense I intend here, is one that involves a change of harmonic function. Throughout the foregoing discussion, I insist that the opening progression of Tristan be taken as a harmonic progression. I do so because I hear the resolution of the Tristan chord to $\mathrm{V}^{7}$ of A as strongly analogous to the progressions $\mathrm{Ger}^{6} \rightarrow \mathrm{V}^{7}, \mathrm{Fr}^{6} \rightarrow \mathrm{V}^{7}$, and $\mathrm{It}^{6} \rightarrow \mathrm{V}^{7}$ (thanks to the resolution of the augmented sixth F-D $\mathrm{D}^{\sharp}$ to E-D). If these latter are harmonic progressions, as I take it most readers will agree they are, then the resolution of the Tristan chord in measures 2-3 should be a harmonic progression as well. But this is not to say that its resolution cannot also be analyzed in linear terms: I certainly do not mean to argue that the opening progression of Tristan is harmonic and not linear. Rather, like many tonal progressions (the resolutions of the other augmented-sixth chords among them), the opening of Tristan can be profitably analyzed from both perspectives. What I do reject is the claim that the opening progression of Tristan is solely a linear progression. I suspect that part of the temptation to this conclusion arises from the fact that there is no conventional label for the halfdiminished seventh chord functioning as an augmented sixth. If so, introducing such a label (e.g. Harrison's term, the "dual augmented-sixth chord") should remove some part of the temptation. Some readers, however, might point out that the Tristan chord differs from other augmented sixth chords in that it shares two common tones with its chord of resolution. In measures 2-3, these two pitches are the $G^{\sharp}$ and $B$ that participate a voice exchange between the soprano and tenor lines. No doubt, these two common tones tend to associate the Tristan chord quite strongly with its chord of resolutionvoice exchanges, moreover, occur most frequently between chords that share a common harmonic function (or indeed, between different voicings of the same chord). First, however, there is no strict requirement that the harmonies joined by a voice exchange express the same function. And second, it seems to me that the aural effect of the $\mathrm{G}^{\sharp}$-B voice exchange in Wagner's Prelude is actually to disguise the retention of these two common tones and to focus the listener's attention instead on the resolution of the augmented sixth F- $D^{\sharp}$. If anything, the voice exchange here makes the progression sound more like the resolution of an augmented-sixth chord that it otherwise might have. Finally, while I by no means object to the claim that, on a slightly more background level, measures 2-3 prolong $\mathrm{V}^{7}$ of $\mathrm{A}, \mathrm{I}$ would emphasize that they do so by means of a double incomplete neighbouring motion (F and $\left.\mathrm{D}^{\sharp}\right)$ that receives harmonic support as a novel but aurally recognizable augmented-sixth chord.

19 My use of the term pre-dominant throughout this article is meant to avoid taking sides on whether augmented-sixth chords are subdominant or applied-dominant harmonies (when they resolve to dominants). As is well known, however, French, German, and Italian sixths can also resolve to tonics (in which case they presumably take on dominant function). Example 11 above and perhaps also example 14 below suggest that the Tristan chord can be used in this way as well.

20 On the relationship between Strauss's tone poem and Wagner's Prelude, see Bribitzer-Stull and Gauldin (2007). 

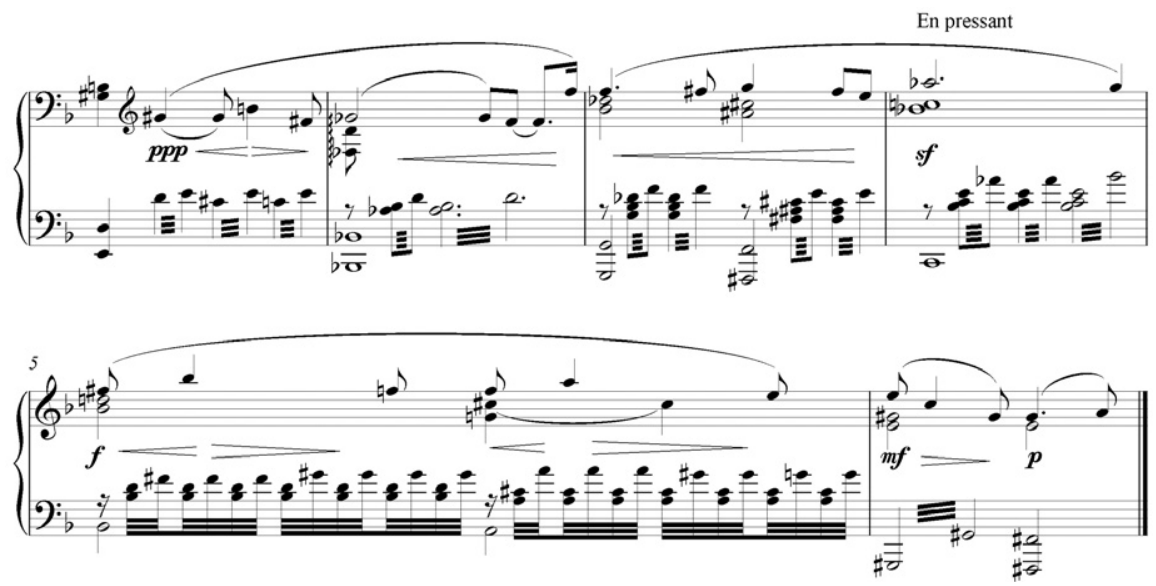

Example 13: Chausson, Le Roi Arthus, Act 3
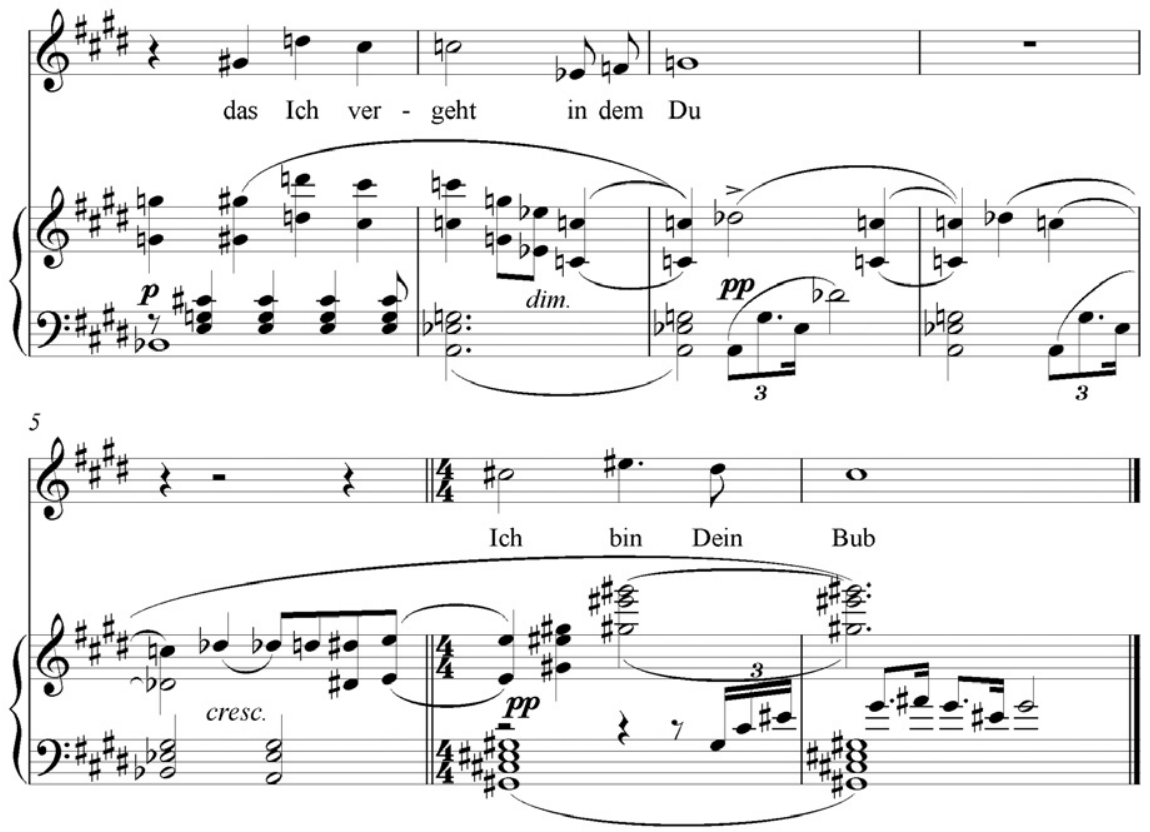

Example 14: Strauss, Der Rosenkavalier, Act 1

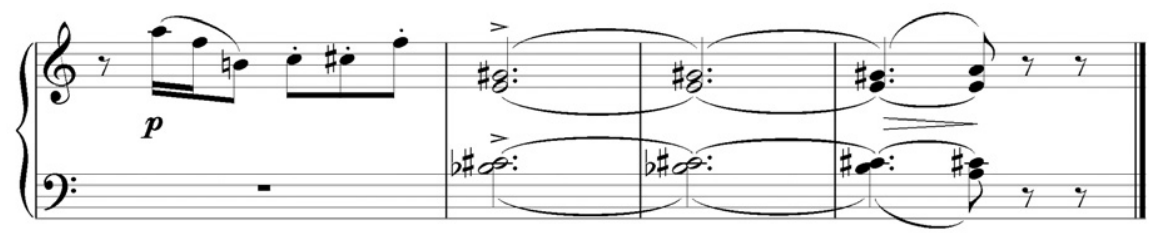

Example 15: Strauss, Til Eulenspiegel, mm. 590-93 
works predating Tristan-or whether Wagner was in this limited sense sui generis-that remains for others to determine. I would stress in concluding only that a genuine antecedent, as opposed to the kinds of passages that have sometimes been cited, would be one in which a half-diminished seventh chord resolves exactly like an augmented sixth-precisely what happens in the opening bars of Tristan.

\section{REFERENCE LIST}

Arend, Max. 1901. Harmonische Analyse des Tristanvorspiels. Bayreuther Blätter 24:160-169.

Babbitt, Milton. 1976. Responses: A First Approximation." Perspectives of New Music 14-15:2-36.

Bailey, Robert. 1985. An analytical study of the sketches and drafts. In Wagner: Prelude and Transfiguration from Tristan und Isolde,113-146. New York: Norton.

Bass, Richard. 1996. From Gretchen to Tristan: The changing role of harmonic sequences in the nineteenth century. Nineteenth-Century Music 19:263-285.

Boretz, Benjamin. 1972. Meta-variations, part IV: Analytic fallout (I). Perspectives of New Music 11:146-223.

Bribitzer-Stull, Mathew, and Robert Gauldin. 2007. Hearing Wagner in Till Eulenspiegel: Strauss's merry pranks reconsidered. Intégral 21:1-39.

Burstein, Poundie. 1983. A new view of Tristan: Tonal unity in the prelude and conclusion to act I. Theory and Practice 8:15-41.

Caplin, William. 1984. Moritz Hauptmann and the theory of suspensions. Journal of Music Theory 28:251-269.

Chailley, Jacques. 1963. Tristan et Isolde de Richard Wagner. Paris: Centre de Documentation Universitaire.

Cohn, Richard. 1996. Maximally smooth cycles, hexatonic systems, and the analysis of late-romantic triadic progressions. Music Analysis 15:19-40.

Cone, Edward T. 1962. Analysis today. In Problems of modern music, ed. P. H. Lang. New York: Norton.

DeVoto, Mark. 1995. The strategic half-diminished seventh chord and the emblematic Tristan chord: A survey from Beethoven to Berg. International Journal of Musicology 4:139-153.

Forte, Allen. 1988. New approaches to the linear analysis of music. Journal of the American Musicological Society 41:315-348.

Gauldin, Robert. 2001. The DOUTH2 relation as a dramatic signifier in Wagner's music dramas. Music Analysis 20:179-192.

Gollin, Edward. 1998. Some aspects of three-dimensional “Tonnetze." Journal of Music Theory 42:195-206.

Gostomsky, Dieter. 1975. Immer noch einmal: Der “Tristan-Akkord.” Zeitschrift für Musiktheorie 6:22-27.

Harrison, Daniel. 1994. Harmonic function in chromatic music: A renewed dualist theory and an account of its precedents. Chicago: Chicago University Press. 
- 1995. Supplement to the theory of augmented-sixth chords. Music Theory Spectrum 17:170-195.

Hauptmann, Moritz. 1853. Die Natur der Harmonik und der Metrik. Leipzig: Breitkopf and Härtel.

. 1888. The nature of harmony and meter, trans. W. E. Heathcote. London: Sonnenschein.

Hill, Cecil. 1984. That Wagner-Tristan Chord. Music Review 45:7-10.

Kirnberger, Johann Philipp. 1979. The true principles for the practice of harmony. Journal of Music Theory 23:163-225.

Kurth, Ernst. 1923. Romantische Harmonik und ihre Krise in Wagner's "Tristan." 3rd ed. Berlin: Max Hesses Verlag.

Lewin, David. 1996. Cohn functions. Journal of Music Theory 40:181-216.

Lorenz, Alfred. 1924. Review of Ernst Kurth: Romantische Harmonik und ihre Krise in Wagners "Tristan." Die Musik 16:255-262.

__. 1926. Der musikalische Aufbau von Richard Wagners "Tristan und Isolde." Berlin: Hesse.

Louis, Rudolf, and Ludwig Thuille. 1928. Harmonielehre. 9th ed. Stuttgart: Ernst Klett.

Mayrberger, Carl. 1881. Die Harmonik Richard Wagner's aus den Leitmotiven des Vorspiels zu Tristan und Isolde erläutert. Bayreuther Blätter 4:169-180.

Nattiez, Jean-Jacques. 1985. The concepts of plot and seriation process in music analysis. Music Analysis 4:107-118.

Rothgeb, John. 1995. The Tristan chord: Identity and origin. Music Theory Online 1.1, http://mto.societymusictheory.org.

Schoenberg, Arnold. 1978. Theory of harmony, trans. R. E. Carter. London: Faber and Faber.

Tymoczko, Dmitri. 2008. Scale theory, serial theory and voice leading. Music Analysis 27:1-49.

Vogel, Martin. 1962. Der Tristan-Akkkord und die Krise der modernen Harmonielehre. Düsseldorf: Verlag der Gesellschaft zur Förderung der systematischen Musikwissenschaft.

Wason, Robert. 1982. Viennese harmonic theory from Albrchetsberger to Schenker and Schoenberg. Ann Arbor: University Microfilms International.

\section{BibLIOGRAPHY}

Good bibliographies of the secondary literature on the Tristan chord can be found in Martin Vogel, Der Tristan-Akkord und die Krise der modernen Harmonielehre (Düsseldorf: Verlag der Gesellschaft zur Förderung der systematischen Musikwissenschaft, 1962), and Kirsten Maegaard, "Analyser af Richard Wagners Tristan-Forspil: En Bibliografi," Musik og Forskning 6 (1980): 49-52. The following citations are meant augment these bibliographies, with particular emphasis on the literature after 1980.

Arlettaz, Vincent. "L'Influence de Liszt sur Wagner: quelques observations sur le langage musical de la Tétralogie." Revue musicale de Suisse Romande 54 (2001): 56-63. 
Arnold, Ben. "Wagner and Liszt: Borrowing, Theft and Assimilation before 1860." Journal of the American Liszt Society 30 (1991): 3-21.

Babbit, Milton. "Responses: A First Approximation." Perspectives of New Music 14-15 (1976): 2-36.

Bailey, Robert. "An Analytical Study of the Sketches and Drafts." In Wagner: Prelude and Transfiguration from "Tristan und Isolde," 113-146. Norton Critical Scores. New York: Norton, 1985.

Bass, Richard. "From Gretchen to Tristan: The Changing Role of Harmonic Sequences in the Nineteenth Century." Nineteenth-Century Music 19 (1996): $263-285$.

__ "Half-Diminished Functions and Transformations in Late Romantic Music." Music Theory Spectrum 23 (2001): 41-60.

Beeson, Roger. "The Tristan Chord and Others: Harmonic Analysis and Harmonic Explanation." Soundings 5 (1975): 55-72.

Berktold, Christian. "Tristan-Bezüge im Till Eulenspiegel von Richard Strauss." Musik in Bayern 69 (2005): 107-111.

Bernstein, Wolfgang, and Helmut C. Jacobs. "Tristan und Isolde aus jazzharmonischer Sicht: Eine Reaktion auf Altug Ünlü.” Musiktheorie 18 (2003): 271-272.

Boretz, Benjamin. “Meta-Variations, Part IV: Analytic Fallout (I).” Perspectives of New Music 11 (1972): 146-223.

Bribitzer-Stull, Mathew, and Robert Gauldin. "Hearing Wagner in Till Eulenspiegel: Stauss's Merry Pranks Reconsidered." Intégral 21 (2007): 1-39.

Caddy, Davinia. "Parisian Cake Walks." Nineteenth-Century Music 30 (2007): 288-317.

Chafe, Eric. The Tragic and the Ecstatic: The Musical Revolution of Wagner's "Tristan and Isolde." Oxford: Oxford University Press, 2005.

Childs, Adrian P. "Moving beyond Neo-Riemannian Triads: Exploring a Transformational Model for Seventh Chords." Journal of Music Theory 42 (1998): 181-193.

Cone, Edward T. "Analysis Today." In Problems of Modern Music, ed. Paul Henry Lang, 34-50. New York: Norton, 1962.

Dahlhaus, Carl. “Tristan'-Harmonik und Tonalität." Melos/Neue Zeitschrift für Musik 4 (1978): 215-219.

Danuser, Hermann. "Der Rätselklang: Zur historischen Semiotik des Tristanakkordes." In Zukunftsbilder: Richard Wagners Revolution und ihre Folgen in Kunst und Politik, edited by Hermann Danuser and Herfried Münkler, 151-16o. Schliengen: Argus, 2002.

- "Tristanakkord." In Musik in Geschichte und Gegenwart, edited by Ludwig Finscher. Sachteil.Vol. 9, 832-444. Kassel: Bärenreiter, 1998.

DeVoto, Mark. "The Strategic Half-Diminished Seventh Chord and the Emblematic Tristan Chord: A Survey from Beethoven to Berg." International Journal of Musicology 4 (1995): 139-153.

Eger, Manfred. "Die Mär vom gestohlenen Tristan-Akkord: Ein groteskes Kapitel der Liszt-Wagner Forschung." Musikforschung 52 (1999): 436-453. 
__. "Wagner-Ein Plagiator? Ein groteskes Kapital in der Liszt Forschung." Liszt Saeculum (1991): 9-17.

Felbick, Lutz. "Kognitive Musikpsychologie: Neue Perspektiven für die Tristan-Analyse?" Musiktheorie 18 (2003): 373-374.

Forte, Allen. "New Approaches to the Linear Analysis of Music." Journal of the American Musicological Society 41 (1988): 315-348.

_- "Tristan Redux: Comments on John Rothgeb's Article on the Tristan Chord in MTO 1.1." Music Theory Online 1.2 (1995), http://mto.societymusictheory.org.

Garcia Laborda, José María. “Una nueva tipología del 'acorde Tristán' en A. Bruckner." Nassarre: Revista Aragonesa de Musicología 16 (2000): 35-68.

Gauldin, Robert. "The DOUTH2 Relation as a Dramatic Signifier in Wagner's Music Dramas." Music Analysis 20 (2001): 179-192.

_. "The Theory and Practice of Chromatic Wedge Progressions in Romantic Music." Music Theory Spectrum 26 (2004): 1-22.

Giesl, Peter. "Der Tristan-Akkord aus der Sicht der Clausellehre." In Der "Komponist" Richard Wagner im Blick der aktuellen Musikwissenschaft: Symposium Würtzburg 200o. Edited by Konrad Ulrich, 117-125. Wiesbaden: Breitkopf and Härtel, 2003.

—. "Von Stimmführungsvorgängen zur Harmonik: Eine Anwendung der Clausellehre auf Wagners Tristan und Isolde." Musikforschung 52 (1999): 403-435.

Gloede, Wilhelm. "Zum Mythos 'Tristan-Akkord.” Musiktheorie 19 (2004): 69-81.

Golab, Maciej. “Über den Tristan-Akkord bei Chopin.” Translated by Beatrysa Hirszenberg. Chopin Studies 3 (1990): 246-256.

Gollin, Edward. "Some Aspects of Three-Dimensional 'Tonnetze."” Journal of Music Theory 42 (1998): 195-206.

Gostomsky, Dieter. "Immer noch einmal: Der 'Tristan-Akkord." Zeitschrift für Musiktheorie 6 (1975): 22-27.

Graubart, Michael. "The Frustrated Supertonic and the Pathetic Added Sixth." International Journal of Musicology 8 (1999): 451-461.

Gut, Serge. "Encore et toujours: 'l'accord de Tristan." L'Avant-scène Opéra 3435 (1981): 148-451.

Hansen, Finn Egeland. "The Tristan Chord Is Nothing but a Tritone Substitution of the Characteristic Subdominant." In Festskrift Jan Maegaard 14.4.1996. Edited by Mogens Andersen, Claus Rollum-Larsen, and Niels Bo Foltmann, 165-83. Copenhagen: Engstrom and Sodring, 1996.

Harrison, Daniel. Harmonic Function in Chromatic Music: A Renewed Dualist Theory and an Account of Its Precedents. Chicago: University of Chicago Press, 1994.

__ . "Supplement to the Theory of Augmented-Sixth Chords." Music Theory Spectrum 17 (1995): 170-195.

Hartmann, Günter. "Schon wieder: Der (?) 'Tristan-Akkord.” Musikforschung 42 (1989): 36-52.

Hill, Cecil. "That Wagner-Tristan Chord.” Music Review 45 (1984): 7-10. 
Holtmeier, Ludwig. "Der Tristanakkord und die Neue Funktionstheorie." Musiktheorie 17 (2002): 361-365.

Huebner, Steven. “Tristan's Traces.” In Richard Wagner: Tristan and Isolde. Edited by Arthur Groos. Cambridge Opera Handbooks. Cambridge: Cambridge University Press (forthcoming).

Hyer, Brian. "Tonal Intuitions in Tristan und Isolde." $\mathrm{PhD}$ diss., Yale University, 1989.

Jackson, Roland. "Leitmotive and Form in the Tristan Prelude." Music Review 36 (1975): 42-53.

- "The 'Neapolitan Progression' in the Nineteenth Century." Music Review 30 (1969): 35-46.

Jan, Steven B. "The Selfish Meme: Particularity, Replication and Evolution in Musical Style." International Journal of Musicology 8 (1999): 9-76.

Keil, Werner. "Von Quarten, Tristan-Akkorden und 'Callots Manier': Bemerkungen zur Musik Mahlers und Debussys um 1900." In 1900: Musik zur Jahrhundertswende. Edited by Werner Keil, 75-97. Hildesheim: Olms, 1995.

Kinderman, William. "Das 'Geheimnis der Form' in Tristan und Isolde." Archiv für Musikwissenschaft 40 (1983): 174-188.

Knapp, Raymond. "The Tonal Structure of 'Tristan und Isolde': A Sketch." Music Review 45 (1984): 11-25.

Kratochwil, Heinz. "Die Tristan-Harmonik." Musikerziehung 44 (1991): 122-128.

Lerdahl, Fred. Tonal Pitch Space. Oxford: Oxford University Press, 2001.

Lewin, David. "Cohn Functions." Journal of Music Theory 40 (1996): 181-216.

Lewis, Christopher. "Mirrors and Metaphors: Reflections on Schoenberg and Nineteenth-Century Tonality." Nineteenth Century Music 11 (1987): 26-42.

Löffler, Wolfgang. "Vom Tritonus und anderen teuflischen Klangen." In Jazz und Avantgarde. Edited by Jürgen Arndt and Werner Keil, 222-237. Hildesheim: Olms, 1998.

Maegaard, Jan. "Forspillet til Tristan und Isolde: Tonalitet på skillevejen." Musik og Forskning 6 (1980): 24-48.

Médicis, François de. "Tristan dans La Mer: le crépuscule wagnérien noyé dans le zénith debussyste." Acta Musicologica 79 (2007): 195-251.

Mitchell, William. "The Tristan Prelude." Music Forum 1 (1967): 163-203.

North, Roger. Wagner's Most Subtle Art: An Analytic Study of "Tristan und Isolde." 2nd rev. ed. London: n. p.

Nattiez, Jean-Jacques. "The Concepts of Plot and Seriation Process in Music Analysis." Translated by Catherine Dale. Music Analysis 4 (1985): 107-118. - Music and Discourse. Translated by Carolyn Abbate. Princeton: Princeton University Press, 1990.

——. Musicologie générale et sémiologie. Paris: Christian Bourgois, 1987. - Wagner androgyne. Paris: Christian Bourgois, 1990.

—_. Wagner Androgyne. Translated by Stewart Spencer. Princeton: Princeton University Press, 1993.

Perle, George. Style and Idea in the Lyric Suite of Alban Berg. New York: Pendragon, 1995. 
Perry, Simon. "Agonising over Orthography: Aspects of Notation from Tristan to Opus 11, No. 1." Musicology Australia 26 (2003): 1-37.

Poos, Heinrich. "Der Dritte Tristan-Akkord: Zur Harmoniestruktur der Takte 1-16 der Einleitung von 'Tristan und Isolde."” In Bericht über den internationalen Musikwissenschaftlichen Kongress Bon 1970. Edited by Carl Dahlhaus, Hans Joachim Marx, Magda Marx-Weber, and Günter Massenkeil, 539-542. Kassel: Bärenreiter, 1971.

_- "Zur Tristanharmonik." In Festschrift Ernst Pepping zu seinem 7o. Geburtstag. Edited by Heinrich Poos, 269-297. Berlin: Merseberger, 1971.

Rehding, Alexander. "Liszt und die Suche nach dem 'TrisZtan'-Akkord." Acta Musicologica 72 (2000): 169-188.

__. "TrisZtan: Or, the Case of Liszt's 'Ich möchte hingehn."” In NineteenthCentury Music: Selected Proceedings of the Tenth International Conference. Edited by Jim Samson and Bennett Zon, 75-97. Aldershot: Ashgate, 2002.

Reiman, Erika. “The 'Tristan' Chord as Music-Historical Metaphor.” University of Toronto Quarterly 67 (1998): 768-773.

Reiter, Elisabeth. "Nochmals: Die 'Wagner-Zitate'-Funktion und Kontext." Bruckner Jahrbuch (1994-1996): 79-89.

Richley, John. "History and the Tristan Chord." Music Review 55 (1994): 97-103. Rosen, Charles. The Romantic Generation. Cambridge: Harvard University Press, 1995.

Rosenmann, Mauricio. "Irrealer Klang_irrealer Satz: Einige Bemerkungen über den Anfang von Tristan und über zwei Préludes von Chopin." Musiktheorie 19 (2004): 257-260.

Roth, Hans Ulrich. "Einmal noch: Der Tristan-Akkord." Musik in Bayern 49 (1994): 79-89.

Rothgeb, John. "The Tristan Chord: Identity and Origin." Music Theory Online 1.1 (1995), http://mto.societymusictheory.org.

Rothstein, William. "The Tristan Chord in Historical Context: A Response to John Rothgeb." Music Theory Online 1.3 (1995), http://mto.societymusictheory.org.

Schlötterer-Traimer, Roswitha. "Akkorde, die einen Namen haben." In Altes im Neuen: Festschrift Theodor Göllner zum 65. Geburtstag. Edited by Bernd Edelmann and Manfred Hermann Schmid, 321-330. Tutzing: Schneider, 1995.

Schmid, Manfred Hermann. "Der 'Tristanakkord.” In Musik als Abbild: Studien zum Werk von Weber, Schumann und Wagner, 263-275. Tutzing: Schneider, 1981.

Schuijer, Michiel. "Een elektronische discussie: Commentaren op John Rothgeb, the Tristan Chord: Identity and Origin." Tijdschrift voor Muziektheorie 1 (1996): 60-62.

Smith, Charles J. "The Functional Extravagance of Chromatic Chords.” Music Theory Spectrum 8 (1986): 94-139.

Solare, Juan María. "El comienzo de Tristán en una canción anterior de Liszt." 12 Notas 45 (2005): 18-20. 
Sonderberg, Stephen. "The T-hex Constellation." Journal of Music Theory 42 (1998): 207-218.

Spohr, Martin. "Wie kommt der 'Tristan-Akkord' in Schuberts Zauberharfe?" Schubert durch die Brille 9 (1992): 139-147.

Straus, Joseph N. “Tristan and Berg's Lyric Suite.” In Theory Only 8 (1984): 33-41. Swinden, Kevin J. "When Functions Collide: Aspects of Plural Function in Chromatic Music." Music Theory Spectrum 27 (2005): 249-282.

Torkewitz, Dieter. "Eine unendliche Geschichte oder: Von der Emanzipation des Einzeltons." Musiktheorie 19 (2004): 177-187.

Tymoczko, Dmitri. "Scale Theory, Serial Theory and Voice Leading." Music Analysis 27 (2008): 1-49.

Ünlü, Altug. "Der 'Tristan-Akkord' im Kontext einer tradierten Sequenzformel." Musiktheorie 18 (2003): 179-185.

Wang, Peter. "Tristan-akkorden oplost." Dansk årbog for Musikforskning 19 (1988-1991): 157-170.

Wilson, Martin. “The 'Tristan Chord': Some Reflections." Wagner 10 (1989): 83-95.

Ziegler, Reinald. "Der 'Tristan-Akkord': ein geschichtliches Phänomen." In Musik und Szene: Festschrift für Werner Braun zum 75. Geburtstag. Edited by Bernhard Appel, Karl W. Geck, and Herbert Schneider, 387-412. Saarbrücken: Saarbrücker Druckerei, 2001.

Zeke, Lajos. "Tristan: The Prelude, the Chord, and the Implications: Postlude to a Musicological Conundrum." PhD dissertation, University of Miama, 1999.

\begin{abstract}
A little-noticed passage from Moritz Hauptmann's 1853 treatise Die Natur der Harmonik und der Metrik very nearly describes the opening progression of Wagner's Tristan. The present paper surveys the various analyses of the Tristan chord presented in the theoretical literature and defends an analysis derived from Hauptmann as a viable alternative.
\end{abstract}

\title{
RÉSUMÉ
}

Un passage peu remarqué du traité de Moritz Hauptmann, Die Natur der Harmonik und der Metrik, offre une description qui pourrait presque décrire la progression initiale de Tristan de Wagner. Cet article survole différentes analyses de l'accord de Tristan publiées dans la littérature spécialisée, et défend les mérites d'une nouvelle interprétation dérivée de celle d'Hauptmann. 